\title{
Housing Price Forecasting in Selected Polish Cities During the COVID-19 Pandemic
}

\begin{abstract}
The COVID-19 pandemic represents a combined supply and demand shock to the financial and housing market but also an unusual negative shock in terms of the health of society (households) and national economy. The fall in housing demand was initially assumed together with price decreases as a consequence of the uncertainty of the health of society, significant falls in stock markets and corporate solvency. However, the results of research in selected Polish cities do not indicate such a significant market recession. This article examines the housing price dynamics and forecasting in Polish cities during the COVID-19 pandemic. The TRAMO/SEATS and ARIMA models were used for the decomposition and forecasting of dwelling time series. The Polish housing market, represented by selected local housing markets, still shows a growing trend despite the COVID-19 pandemic throughout 2020. The housing market may slow down in 2021, but the strong forecasted growth trends in Warszawa and Poznań suggest that there will be no significant price decline in Poland in the near future.
\end{abstract}

Keywords: housing market, housing price dynamics, COVID-19 pandemic

Received: 11 May 2021, accepted: 12 July 2021

(C) 2021 Author. This is an open access publication, which can be used, distributed and reproduced in any medium according to the Creative Commons CC-BY 4.0 License.

1 University of Warmia and Mazury in Olsztyn, Department of Spatial Analysis and Real Estate Market, Olsztyn, Poland, email: miroslaw.belej@uwm.edu.pl, ORCID ID: https://orcid.org/0000-0001-8650-6990 


\section{Introduction}

The Severe Acute Respiratory Syndrome Coronavirus 2 (SARS-CoV-2) or coronavirus disease 2019 (COVID-19) is a global pandemic which the world is currently facing. The COVID-19 pandemic is an unusual negative shock to society (households), financial markets, and national economies. It has sparked an ongoing debate on the obvious negative outcomes (as well as unobvious positive influences), which primarily concern the health of the population and the country's economy. The debate about the socio-economic implications of the coronavirus pandemic concerns the financial markets [1], manufacturing industry [2], agriculture [3], tourism [4], aviation [5], sports industry [6], domestic violence [7] and others. The implications of the COVID-19 pandemic have led to the widely held view that the current pandemic impacts economies as a combined supply and demand shock [8-10].

It seems that beyond the obvious areas for studying the impact of COVID-19, such as health, the state of small and large businesses, or the stability and instability of financial markets, it is now an appropriate time for studies on its effects on housing markets [11, 12], which represent a safe investment zone in periods of financial market downturns. The United Nations [13] confirms that urban systems, as the centre of human production and life (approximately 55\% of the world's population, 4.2 billion inhabitants), are the ground zero of the COVID-19 pandemic, with $90 \%$ of reported cases. The urban space zone is a multilayer spatial structure gathering people and products of their activities in nearby places [14-18]. There is a strong positive feedback between the specific nature of an urban area (which arises from the local features of cities in a geospatial, economic, administrative, and social sense), and the function of the housing market, which at the same time responds to megatrends in the market environment. The housing market is - on the one hand - a factor which stimulates the process of change of the urban space and, on the other, the actions of space users change the conditions of the operation of this market [19, 20]. Housing is [21] a special type of commodity because is a spatially immobile, highly durable, costly, multidimensionally heterogeneous, and physically modifiable commodity. These characteristics shape attitudes and behaviors towards housing and, in turn, influence neighbourhood characteristics, mortgage markets, national housing policies, and urban growth.

This article examines the housing price dynamics and forecasting in Poland, both before and during the COVID-19 pandemic. The research was carried out at the city level in Poland and focused on the primary market of dwellings in four selected Polish cities (Warszawa, Kraków, Poznań, and Gdańsk). The source of the data (time series of dwelling prices) is the Residential Property Price Database (BaRN) of National Bank of Poland. The time horizon is from Q3, 2006 to Q4, 2020. A Time series Regression with ARIMA noise, Missing values and Outliers (TRAMO) and Signal Extraction in ARIMA Time Series (SEATS) and the ARIMA model were used for the decomposition and forecasting of the time series. 
The paper is organized as follows. After the introduction, the next section presents a description of the research methods used. The third section presents the results with data description, preliminary studies, and time series analysis. Section four presents a discussion of the research results linked to the literature review of the topic. The last section presents the conclusions drawn from this work.

\section{Methods}

The economic time series generally involves four components such as trend (T), seasonality (S), cycle (C), and irregular fluctuations (I). Among them, seasonality is a kind of regular fluctuation that is repeated year after year due to climatic seasons, fixed holidays, and other factors. In time series analyses, seasonal fluctuations may be misjudged and confused with normal changes in the economy. Therefore, seasonal adjustments are carried out first, in order to further analyze and forecast the examined economic factor [22]. Seasonality is defined as a regularly recurring relationship between observations that are a fixed number of periods apart. The occurrence of seasonal variations in a time series makes it difficult to compare and interpret changes in a phenomenon from period to period. The occurrence of seasonality requires a special approach to smoothing and forecasting, as it becomes an important factor influencing the behaviour of the series.

Two types of seasonal fluctuations can be distinguished:

1) additive - characterised by a constant absolute amplitude of fluctuations, seasonal fluctuations have approximate values,

2) multiplicative - characterised by a constant relative amplitude of fluctuations, seasonal fluctuations increase or decrease in subsequent periods.

In the additive model, values of the observed variables are the sum of components occurring in the series. In the multiplicative model, values of the observed variable are a product of these components. Assuming the following designations [23]:

$f_{t}$ - trend or constant level of the observed variable,

$s_{t}-$ function describing seasonal fluctuations,

$c_{t}-$ function describing cyclical fluctuations,

$e_{t}-$ irregular component.

We obtain for the additive model and multiplicative model:

$$
\begin{gathered}
y_{t}=f_{t}+s_{t}+c_{t}+e_{t} \\
y_{t}=f_{t} \cdot s_{t} \cdot c_{t} \cdot e_{t}
\end{gathered}
$$

Once the components of the time series of the observed variables have been determined, the decomposition proceeds. Seasonal smoothing makes it possible to determine the real direction of medium- and long-term changes in individual 
periods by removing short-term fluctuations which determine the seasonal factor characteristic of a given period. According to Cleveland and Tiao [24], one way of effecting the decomposition of a series into seasonal and trend components is to fit a model which has deterministic, seasonal, and nonseasonal parts to the data. It is also possible to separate these components by simply applying different moving average filters.

Decompositions of the time series of dwelling prices in four Polish cities were carried out according to the TRAMO/SEATS procedure in this study. TRAMO (Time series Regression with ARIMA noise, Missing observations, and Outliers) and SEATS (Signal Extraction in ARIMA Time Series) are linked programs developed by Victor Gomez and Agustin Maravall [25, 26] to seasonally adjust time series using ARIMA model-based signal extraction techniques. TRAMO/SEATS uses signal extraction with filters derived from an ARIMA-type time series model that describes the behavior of the series [27]. The ARIMA models (stochastic or time series models) provide a systematic empirical method for forecasting and analyzing of time series. The application of the ARIMA model allows us to deal with the problem of the non-stationarity of time series data. The ARIMA model is due to the combination of the autoregressive (AR) and moving average (MA) parts. The nonseasonal part of the ARIMA model (AR) can be expressed as [27, 28]:

$$
\varnothing(B) \nabla d Z t=\theta(B) a t
$$

where $\varnothing(B)$ and $\theta(B)$ are polynomials of $p$ and $q$ order, respectively. Meanwhile, the seasonal part of the ARIMA model that defines the multiplicative seasonal model can be written as:

$$
\varnothing p(B) \Phi P(B s) \nabla d \nabla s D Z t=\theta q(B) \Theta Q(B s) a t
$$

where $p, d$, and $q$ are nonnegative integers that refer to the order of the autoregressive, integrated, and moving average parts of the model, respectively, and $P, D, Q$ and $S$ are the order of seasonal auto-regression, the number of seasonal differencing, the order of seasonal moving average and the length of the season, respectively. $\varnothing p, \Phi P, \theta q$, and $\Theta Q$ are the coefficients of the polynomials. Complementing the ARIMA model with a component resulting from the seasonality of the analysed process, we construct it as Seasonal ARIMA (SARIMA). The AR and MA create the multiplicative ARIMA $(p, d, q),(P, D, Q)$ model, where $(p, d, q)$ is the nonseasonal part and $(P, D, Q)$ is the seasonal part of the model. Following the notation introduced by Box and Jenkins, $p$ is the order (number of time lags) of the autoregressive model, $\mathrm{d}$ is the degree of differencing (the number of times the data have had past values subtracted), and $q$ is the order of the moving average model, $P, D, Q$ refer to the autoregressive, differencing, and moving average terms for the seasonal part of the ARIMA model. TRAMO/SEATS procedure [26] allows several algorithms 
are available for computing the likelihood or more precisely, the nonlinear sum of squares to be minimized. When a differenced series can be used, the algorithm of Morf, Sidhu, and Kailath was implemented. This simplification extends to multiplicative seasonal moving average models. For the non-differenced series, it is possible to use the ordinary Kalman filter or its square root version. The latter is adequate when numerical difficulties arise, however, it is markedly slower. By default in TRAMO/SEATS procedure, the exact maximum likelihood method is employed, and the unconditional and conditional least squares methods are available as options. Nonlinear maximization of the likelihood function and computation of the parameter estimates and standard errors were made using Marquardt's method and first numerical derivatives. Estimation of regression parameters is made by using the first Cholesky decomposition of the inverse error covariance matrix to transform the regression equations. Then, the resulting least squares problem is solved by applying the QR algorithm [25].

Identification of the values of nonseasonal $(p, d, q)$ and seasonal $(P, D, Q)$ parts of the ARIMA model were conducted using the AUTO-ARIMA procedure developed by Tarassov to fit best the SARIMA model to the univariate time series. It returns the best SARIMA model according to either AICC (corrected AIC), BIC (Schwarz Bayesian criterion), and HQC value (Hannan-Quinn criterion). The optimum is reached when the AIC, BIC, or HQC criteria reach the lowest value. AICC minimises the forecast error and BIC together with HQC aim at the expected value of the true model. If all three criteria indicate the lowest value for the same model, then we have a strong basis for choosing this model.

\section{Results}

The research, as multi-case study, was carried out as follows. Firstly, the demographic and spatial hierarchy of cities in Poland was briefly presented, with characteristics of the cities selected for the study. Next, preliminary analyses of collected dwelling prices in the years 2006-2020 were conducted. The TRAMO/SEATS, AUTO-ARIMA and ARIMA models were used in the next stage of study. The last step of the study was forecasting through the ARIMA model in the COVID-19 pandemic period.

The quarterly time series of average prices per square metre of dwellings on the housing primary market was adopted for the study (see 3.1). Minute, hourly, daily or weekly time series used in financial markets have no place on the housing market. As a rule, a monthly or quarterly time series is used in this market because it differs from the financial market since:

- real estate is highly heterogeneous,

- strong lag and inertia to external stimuli,

- uneven number of transactions in periods and their relatively small number. 
The peculiarity of the housing market is that the average or median price in each period of the time series is based on different data. The phenomenon of repeated sales of the same commodity over short periods of time is practically non-existent in the housing market. As a rule, once you buy a dwelling, you live in it for several years. That's why Kokot [29] proposed to significantly alleviate this problem by extending the periods for which average unit values are calculated. Another specificity of this market is the time lag between the actual date of sale and the date of the decision to buy and pricing, which is usually the same date in the financial market. This problem stems from the specificity of systems for registering rights to a property [30] and the whole cadastral system [31]. Additionally, the housing market shows significant inertia in responding to changes in the macroeconomic environment. The level of inertia is months, quarters, or even years, which is different from the reaction time of the financial markets. For more on this subject, see the study of Bełej [19]. Another peculiarity of the housing market is the low volume of transactions. There are weeks with few or no sales transactions on the local housing markets. The average or median of monthly or quarterly prices is calculated (depending on the size of the city in Poland) from several dozen or several hundred transactions.

\subsection{Data Description and Preliminary Studies}

The subject of the research is the dynamics of housing prices in Polish cities. According to the Central Statistical Office [32] there are 954 cities in Poland. Only Warszawa can be classified as a large city (population over 1 million and area over $500 \mathrm{~km}^{2}$ ). The level of population between 500,000 and 1 million can be found only in 4 Polish cities: Kraków, Łódź, Wrocław, and Poznań. On the other hand, 6 cities, i.e., Gdańsk, Szczecin, Bydgoszcz, Lublin, Białystok and Katowice have a population between 250,000 and 499,999, while 26 cities have a population between 100,000 and 249,999, and 45 Polish cities have a population between 50,000 and 99,000. The rest of the small towns have populations below 50,000. Research conducted as a multi-case study requires a decision on the procedure for selecting cities as local markets. In this research, no attempt was made to map the demographic or spatial structure in the selection of cities. A research decision was taken to select several cities from the group of the largest cities. This group of cities, due to its economic and political importance, is the most responsive to the influence of the market environment. For this group of cities, the national capital city has particular relevance and should therefore be the first to be included in the study. The remaining cities were selected because of their importance as economic, cultural and administrative centers of voivodships, taking into account a relatively even spatial distribution in the country.

Warszawa (as the capital of Poland), Kraków (former capital of Poland and an important cultural and tourist centre), Poznań (central economic area), and Gdańsk (important seaport) were selected for this multi-case study. Table 1 shows the main statistical data for the selected towns. 
Table 1. Main statistical descriptors of selected towns in Poland

\begin{tabular}{|l|c|c|c|c||}
\hline \multicolumn{1}{|c|}{ Town } & Area $\left[\mathrm{km}^{2}\right]$ & Populations & $\begin{array}{c}\text { Population density } \\
{\left[\text { people } / \mathrm{km}^{2}\right]}\end{array}$ & $\begin{array}{c}\text { Budget expenditure } \\
\text { per capita [EUR] }\end{array}$ \\
\hline \hline Warszawa & 517 & $1,715,517$ & 3317 & 1764 \\
\hline Kraków & 327 & 758,463 & 2321 & 1315 \\
\hline Poznań & 262 & 550,742 & 2103 & 1357 \\
\hline Gdańsk & 262 & 460,427 & 1758 & 1306 \\
\hline
\end{tabular}

Source: Central Statistical Office [32]

The analysis of price dynamics in the housing market was conducted in the years 2006-2020 (with the COVID-19 period). The time series of dwelling prices, from Q3 2006 to Q4 2020, were obtained from the Residential Price Database maintained by the National Bank of Poland. In this database only quarterly averages of dwelling prices are available. Table 2 presents the basic statistical descriptors of quarterly average dwelling prices (per square metre) time series on the primary markets in selected towns. Figure 1 shows the box chart and histograms of the time series under analysis.

Table 2. Basic statistical descriptors of the time series Q3 2006 - Q4 2020 in selected towns in Poland

\begin{tabular}{||l|c|c|c|c|c|c||}
\hline \multicolumn{1}{|c|}{ Variable } & $\begin{array}{c}\text { Mean } \\
{[\text { PLN] }}\end{array}$ & $\begin{array}{c}\text { Minimum } \\
{[\text { PLN] }}\end{array}$ & $\begin{array}{c}\text { Maximum } \\
{[\text { PLN] }}\end{array}$ & $\begin{array}{c}\text { Standard } \\
\text { deviation }\end{array}$ & Skewness & Ex. kurtosis \\
\hline Warszawa & 7837.5 & 5605.0 & $10,261.0$ & 890.70 & 0.66722 & 1.0102 \\
\hline Kraków & 6959.7 & 5722.2 & 8837.6 & 782.80 & 0.55590 & -0.40363 \\
\hline Poznań & 6398.4 & 3620.8 & 7610.8 & 672.97 & -1.0907 & 3.9774 \\
\hline Gdańsk & 6427.8 & 3494.0 & 9401.1 & 1183.60 & 0.70710 & 0.17851 \\
\hline
\end{tabular}

Table 2 and Figure 1 present the basic descriptive statistics and box plots and histogram plots of the time series from four Polish cities (2006-2020). Average and median prices are highest in Warszawa, an obvious trend as it is the capital of Poland and an important administrative, economic, and cultural centre. Average prices in the other cities (Kraków, Poznań, and Gdańsk) do not exceed 7000 PLN/m² [about $1600 \mathrm{EUR} / \mathrm{m}^{2}$ (euro exchange rate 4.39 PLN 25.05.2021)], with the lowest prices in Poznań. The differences in prices in individual cities are clearly visible on the box plot. In addition, differences in the price range can be seen with the density of outliers. The highest price range is observed in Gdańsk, which results from its spatial structure. In Gdańsk, apart from the city centre, we also have an investment 
zone along the Gulf of Gdańsk (sea view dwellings). That is why the most expensive dwellings in Gdansk are more expensive than the most expensive ones in Kraków and Poznań (although average prices are lower in Gdańsk).

a)

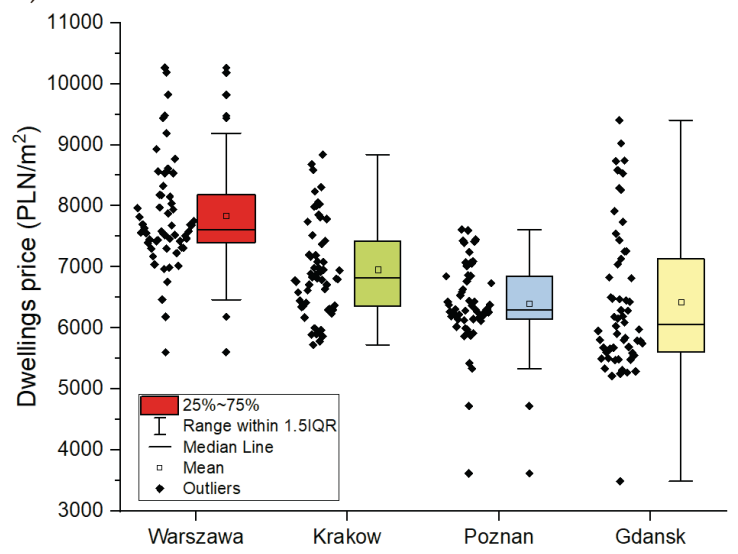

b)

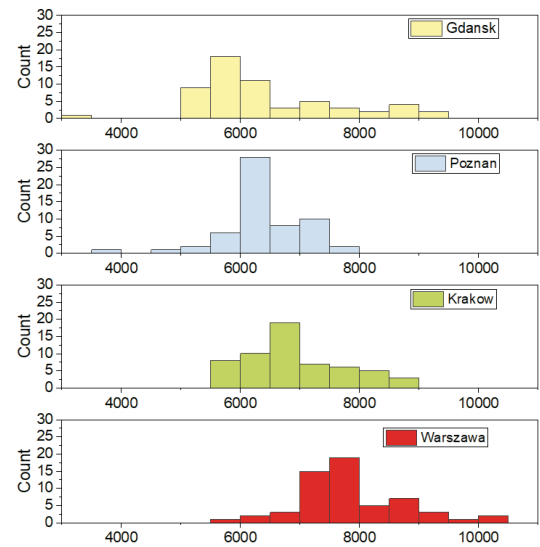

Fig. 1. Basic statistics of the time series Q3 2006 - Q4 2020 in selected towns in Poland: a) box plot; b) histogram plot

Figure 2 shows the time series of the average quarter-based prices per square metre of dwellings in the primary market and in Warszawa, Kraków, Poznań, and Gdańsk.

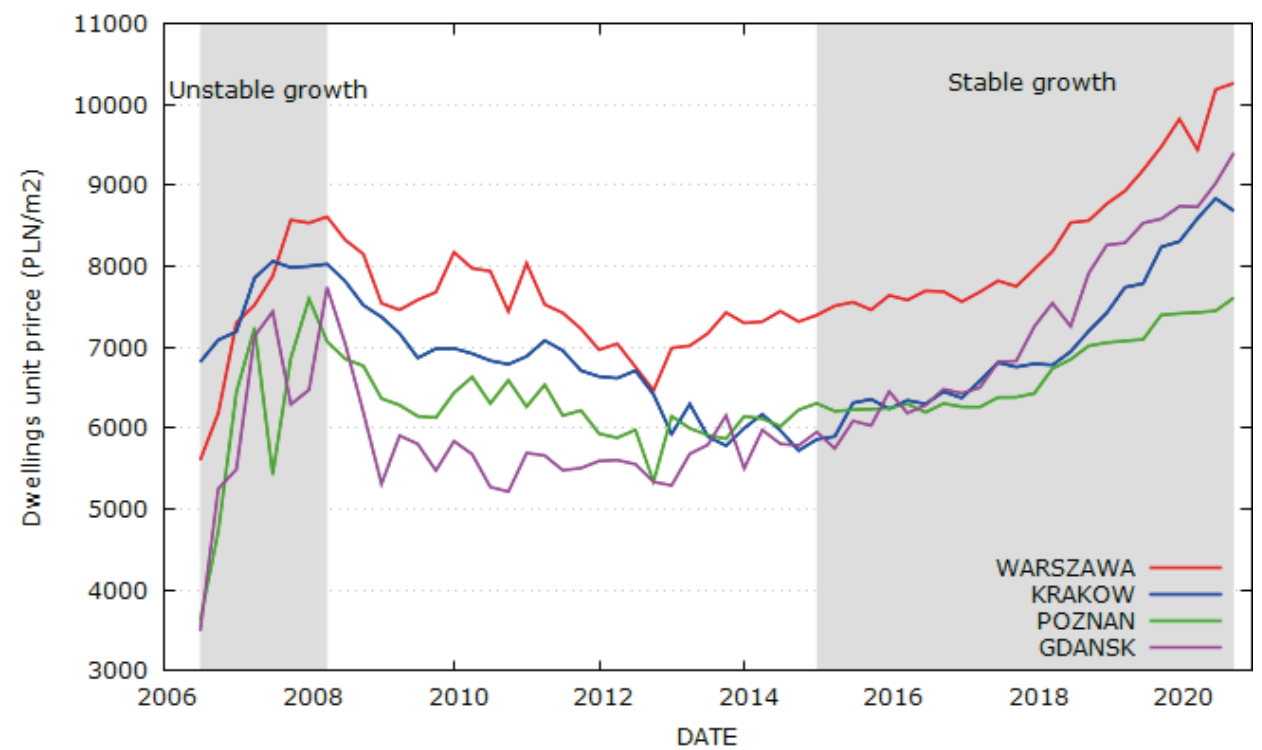

Fig. 2. Time series of average quarter-based prices of dwellings on the primary market in Warszawa, Kraków, Poznań, and Gdańsk (2006-2020) 
The time horizon of the study is 2006-2020. Poland joined the European Union in 2004 and as a result of the economic boom and significant increases on the stock exchange, the housing market also increased. Average dwelling prices reached their historic peak between 2006 and 2007. During these years, dwelling prices increased rapidly (they became a vehicle for speculative financial investment). This period was called a price bubble and an unstable or turbulent evolution [33-35]. Such a rapid increase was unique in the 25-year history of the Polish dwelling market. During this period, a strong synergy of dwelling prices with local housing markets was also noted $[19,20]$. This period is called unstable growth, which has been shown in Figure 2. Housing prices in Poland decreased from 2008 to 2013. Figure 2 clearly shows the asynchronicity of housing price evolution paths in this period, especially of the time series of Gdańsk. At this stage of price evolution, a significant price range is visible (Warszawa - Gdańsk). Thereafter, a period of transition from decline to increase were observed in 2014-2015. Dwelling prices exceeded the previous maximum peaks from 2006-2007, in 2016-2020. This period is called stable growth, which has been shown in Figure 2. The question now is whether housing prices will rise or fall under the impact of the COVID-19 pandemic? In the next stage of the study, time series analyses will be carried out together with a forecasting procedure.

\subsection{Time Series Analyses and Forecasting}

Time series analysis and forecasting allows the presentation of an event or process in dynamic terms. Dynamics refers to forces that cause an object, phenomenon, or process to move $[36,37]$. In this sense, the dynamics of the object $(x)$, is a function of time $(t)$, thus $x=f(t)$. Dynamics therefore aims to describe the variability of a phenomenon over time. Comparisons are made of the quantities of certain phenomena at different times or periods to draw conclusions as to the regularities which occur in them. Time is not the cause of change here, but it expresses changes in the environment in which the phenomenon occurs [38]. The time series illustrates the evolution of the phenomenon under study, shaped by a large number of factors with different characteristics, strengths, and time of influence [39]. Time series analysis is the process concerned with identifying different aspects of the time series, which can be used to better clean, understand, and forecast the data. Decomposing a time series involves separating the individual components of a time series and measuring them [40], as certain regularities characterizing price development are implicit in the particular structure of the time series. It is assumed that the price development over time $t\left(Y_{t}\right)$ is a function of trend $\left(T_{t}\right)$, cyclical fluctuation $\left(C_{t}\right)$, seasonal fluctuation $\left(S_{t}\right)$, and incidental fluctuation $\left(I_{t}\right)$ [41-44]. Often trend and cyclical fluctuations are not separated and are treated as so-called trend/cycle $\left(T C_{t}\right)$.

The TRAMO/SEATS, AUTO-ARIMA and ARIMA models were used in this study for the decomposition and forecasting of time series. The first stage of the research involved the decomposition of time series of quarterly dwelling prices in 
Warszawa, Kraków, Poznań, and Gdańsk (2006-2020) using the TRAMO/SEATS procedure. The Time series Regression with ARIMA noise, Missing values and Outliers (TRAMO) and Signal Extraction in ARIMA Time Series (SEATS) were developed by Victor Gómez and Agustín Maravall [25]. Figure 3 shows the results of the TRAMO/SEATS decomposition of four time series of quarterly dwelling prices in Warsaw, Kraków, Poznań, and Gdańsk. For each of the cities, the empirical time series (red line) and the trend-cyclical component (blue line) as a result of the decomposition procedure are visible. Additionally, irregular fluctuations can be observed.

a)
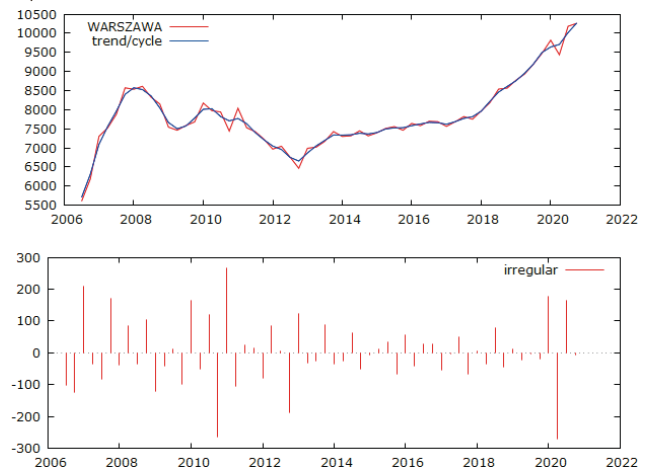

c)
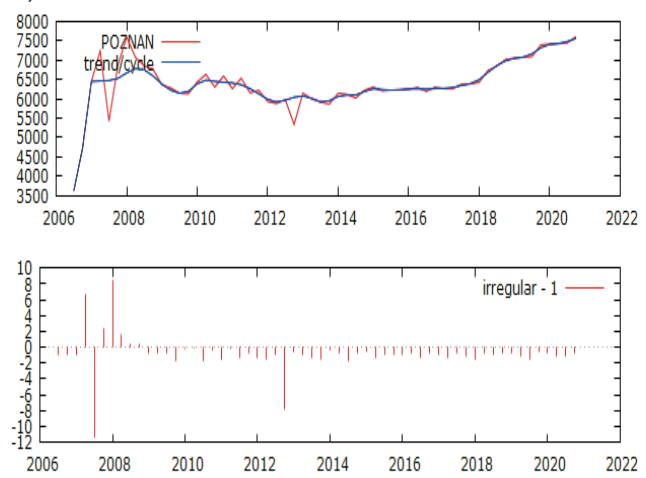

b)
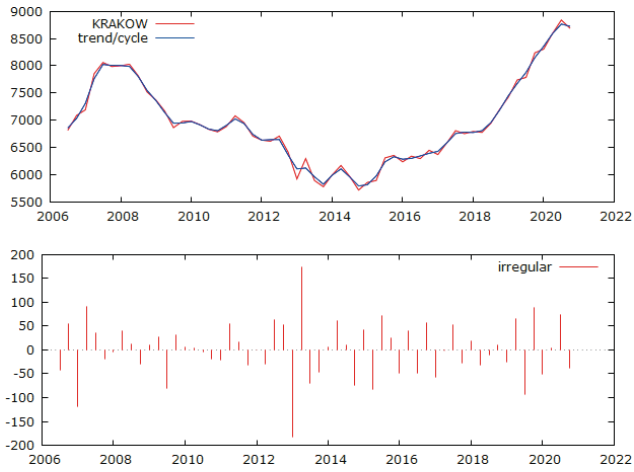

d)
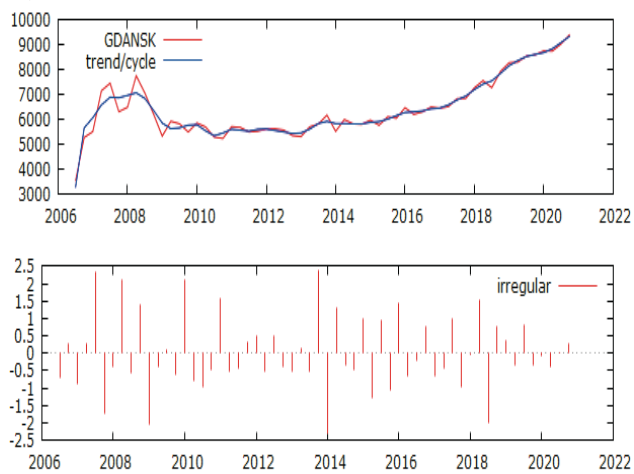

Fig. 3. Results of the TRAMO/SEATS decomposition procedure:

a) Warszawa; b) Kraków; c) Poznań; d) Gdańsk

In the next stage of the research, the AUTO-ARIMA procedure developed by Tarassov was applied to fit the best ARIMA model parameters to the decomposed time series. This procedure simply and efficiently returns best ARIMA model according to either AICC (corrected AIC), BIC (Schwarz Bayesian criterion), and HQC value (Hannan-Quinn criterion). The function conducts a (brute force) search 
over possible models within the order constraints provided. Based on the results of the fit best estimation of the ARIMA model presented in Table 3, the following parameters of ARIMA $(p, d, q)(P, D, Q)$ model were selected: for Warszawa $(1,1,1)(0,0,0)$, for Kraków $(4,0,1)(0,0,0)$, for Poznań $(2,1,1)(0,0,0)$, and for Gdańsk $(1,1,1)(0,0,0)$.

Table 3. Estimation best fit $\mathrm{ARIMA}(\mathrm{X})$ model with decomposed time series of dwelling prices

\begin{tabular}{|c|c|c|c|c|}
\hline Variable & ARIMA-spec & AICC & BIC & HQC \\
\hline \multirow{3}{*}{ WARSZAWA_tc } & $1|1| 1|0| 0 \mid 0$ & $645.665^{* * *}$ & $653.141^{* * *}$ & $648.254^{* * *}$ \\
\hline & $2|1| 1|0| 0 \mid 0$ & $647.038^{*}$ & $656.166^{* *}$ & $650.057^{* *}$ \\
\hline & $4|1| 1|0| 0 \mid 0$ & $646.599^{*}$ & $658.735^{*}$ & $650.181^{*}$ \\
\hline \multirow{3}{*}{ KRAKÓW_tc } & $4|0| 1|0| 0 \mid 0$ & $644.157^{* * *}$ & $656.292^{*}$ & $647.739^{* * *}$ \\
\hline & $2|0| 1|0| 0 \mid 0$ & $646.776^{* *}$ & $655.905^{* *}$ & $649.796^{* *}$ \\
\hline & $1|1| 1|0| 0 \mid 0$ & $648.282^{*}$ & $655.758^{* * *}$ & $650.870^{*}$ \\
\hline \multirow{3}{*}{ POZNAŃ_tc } & $2|1| 1|0| 0 \mid 0$ & $558.520^{* * *}$ & $567.649^{* * *}$ & $561.539^{* * *}$ \\
\hline & $3|1| 1|0| 0 \mid 0$ & $558.729^{* *}$ & $569.413^{* *}$ & $562.082^{* *}$ \\
\hline & $4|1| 1|0| 0 \mid 0$ & $559.095^{*}$ & $571.231^{*}$ & $562.678^{*}$ \\
\hline \multirow{3}{*}{ GDAŃSK_tc } & $1|1| 1|0| 0 \mid 0$ & $649.146^{* * *}$ & $656.622^{* * *}$ & $651.735^{* * *}$ \\
\hline & $2|0| 1|0| 0 \mid 0$ & $649.470^{* *}$ & $658.599^{* *}$ & $652.489^{* *}$ \\
\hline & $3|0| 1|0| 0 \mid 0$ & $650.971^{*}$ & $661.654^{*}$ & $654.323^{*}$ \\
\hline
\end{tabular}

* Three, two, and one asterisk(s) indicate the $1^{\text {st }}, 2^{\text {nd }}$, and $3^{\text {rd }}$ best (that is, minimized) values of the respective information criteria, AICC = corrected AIC, BIC = Schwarz Bayesian criterion and HQC = Hannan-Quinn criterion across all ARIMA model specifications.

The application of the ARIMA model to forecast housing prices in Poland during the COVID-19 pandemic, requires a brief introduction to this period. The COVID-19 pandemic officially began in March 2020 in Poland. A total of almost two million people were infected with SARS-CoV-2, of which about 50,000 died. Figure 4 shows the development of the COVID-19 pandemic (number of daily infections) from March to December 2020. 


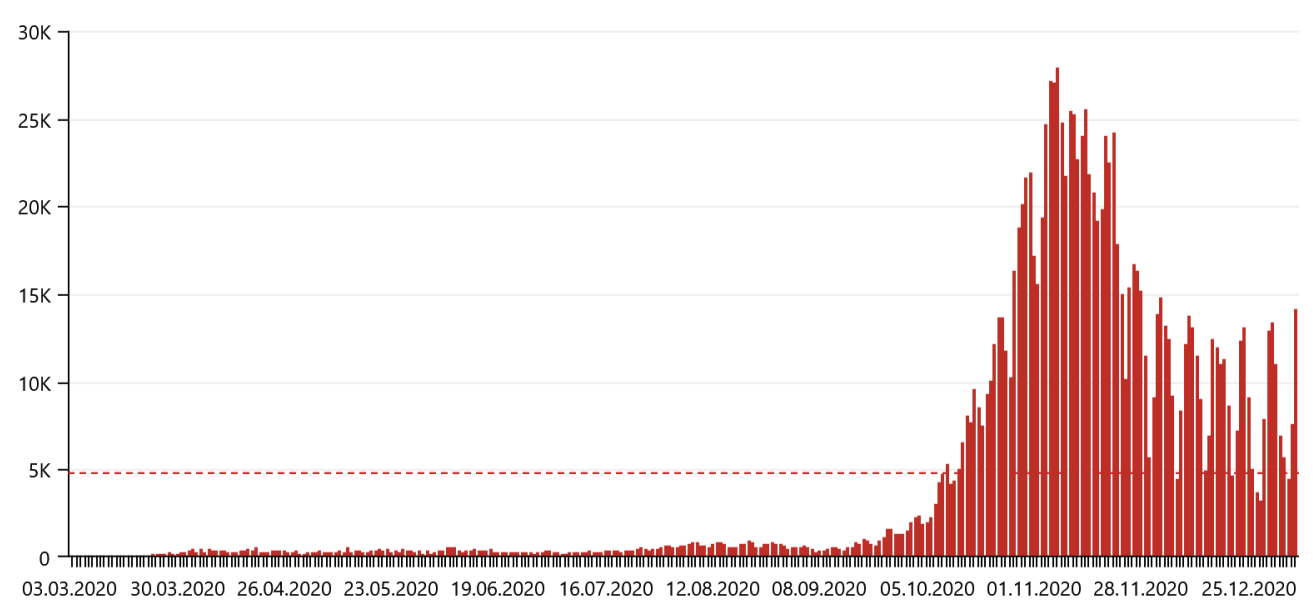

Fig. 4. Number of daily SARS-CoV-2 infections in Poland from March to December 2020 Source: https://koronawirusunas.pl/

The number of daily infections did not exceed 700 during the initial expansion phase of the pandemic (March to August 2020). There was then a significant increase from August 2020 to November 2020 (a maximum of 27,000), with infection levels falling to an average of around 10,000 daily infections by the end of December 2020.

Figure 5 shows the decomposed time series of dwelling prices on the primary market in Warszawa, Kraków, Poznań, and Gdańsk (2018-2021) together with the COVID-19 pandemic period.

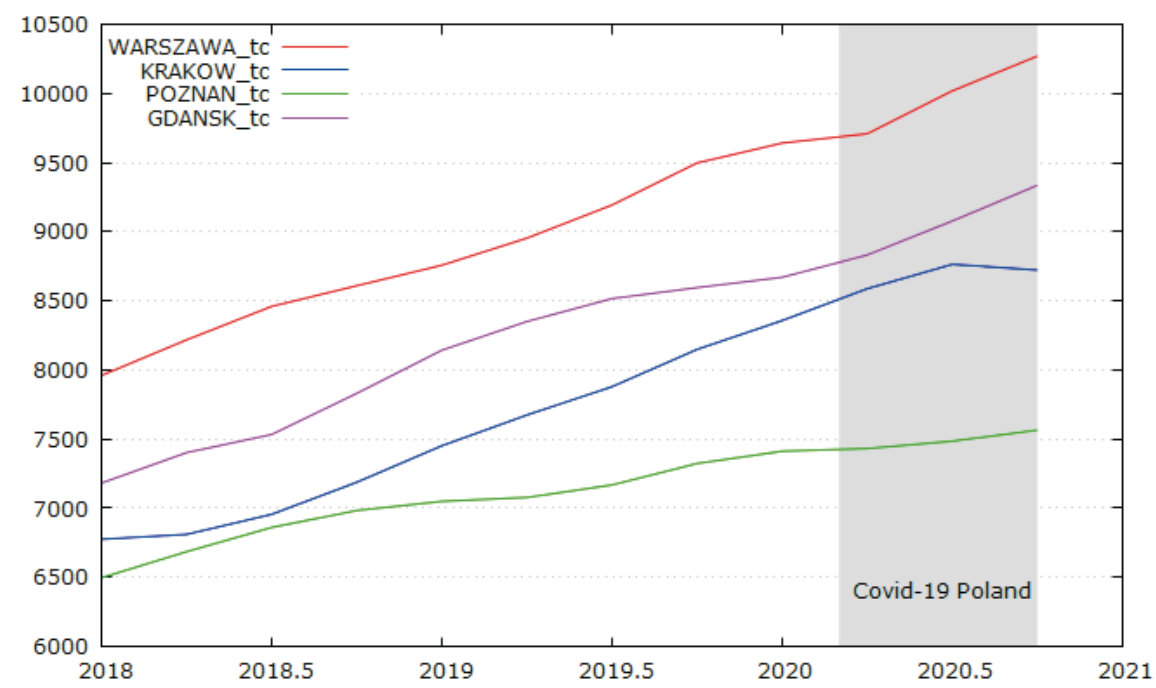

Fig. 5. Time series of average quarter-based prices of dwellings of the primary market with TRAMO/SEATS decomposition in Warszawa, Kraków, Poznań, and Gdańsk (2018-2020) together with the Covid-19 pandemic period (grey) 
It can be clearly seen (Fig. 4) that the previous upward trend of housing prices has not generally changed. Only Kraków has seen a downward trend since May 2020 (or it is only a correction). By April 2020, apartment prices in Warszawa and Gdańsk had been even increased more than before. In Poznań, housing prices continued their steady slow rise following the start of the COVID-19 pandemic. Based on this graphical analysis of price dynamics, it can be assumed that the COVID-19 pandemic has not stopped the dwelling price increases in Poland. Objectively, this is quite unexpected since other markets, such as financial, experienced high asset declines in the first months of the pandemic. According to Fernandez-Perez et al. [45] most of the 63 countries in their research, using the Morgan Stanley Capital International (MSCI) total return indices, experienced negative returns over the first three weeks surrounding their respective countries' first COVID-19 infected case announcement. This is also confirmed by Ali et al. [46] and other researchers [47-49] stating that COVID-19 pandemic brought nearly half the world to a standstill and affected the financial markets by eroding a quarter of wealth in nearly a month.

However, on the other hand, an intrinsic feature of the housing market is its inertia, which means that it responds slowly to changes in the market environment. In the next stage of the research, a price forecasting procedure was carried out, which will assess whether the price dynamics will change in the future.

A forecasting procedure was then carried out for the analysed time series using integrated autoregressive and moving average models (ARIMA), based on the established values of the parameters. A 4-month forecasting period in 2021 was assumed for all-time series (2006-2020). The forecasting results for these series are shown in Figures 6 and 7 for the COVID-19 pandemic period in Poland (from March 2020).

a)

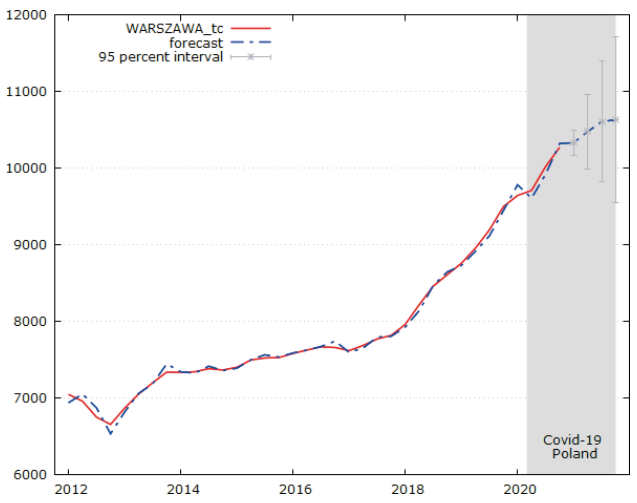

b)

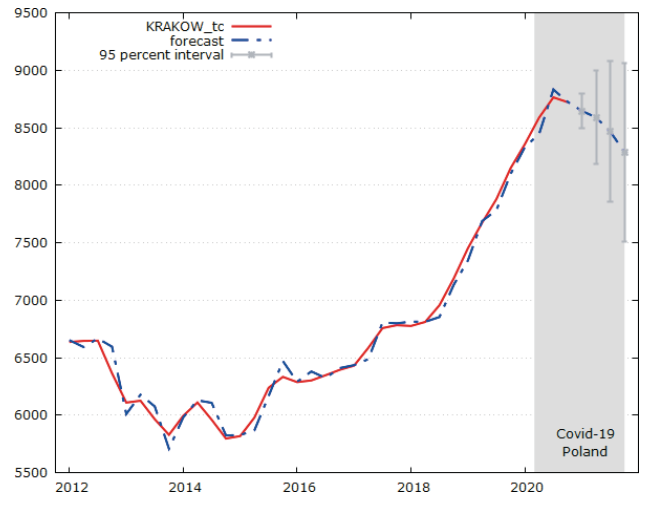

Fig. 6. Time series forecasting results showing the COVID-19 pandemic period: a) Warszawa; b) Kraków 

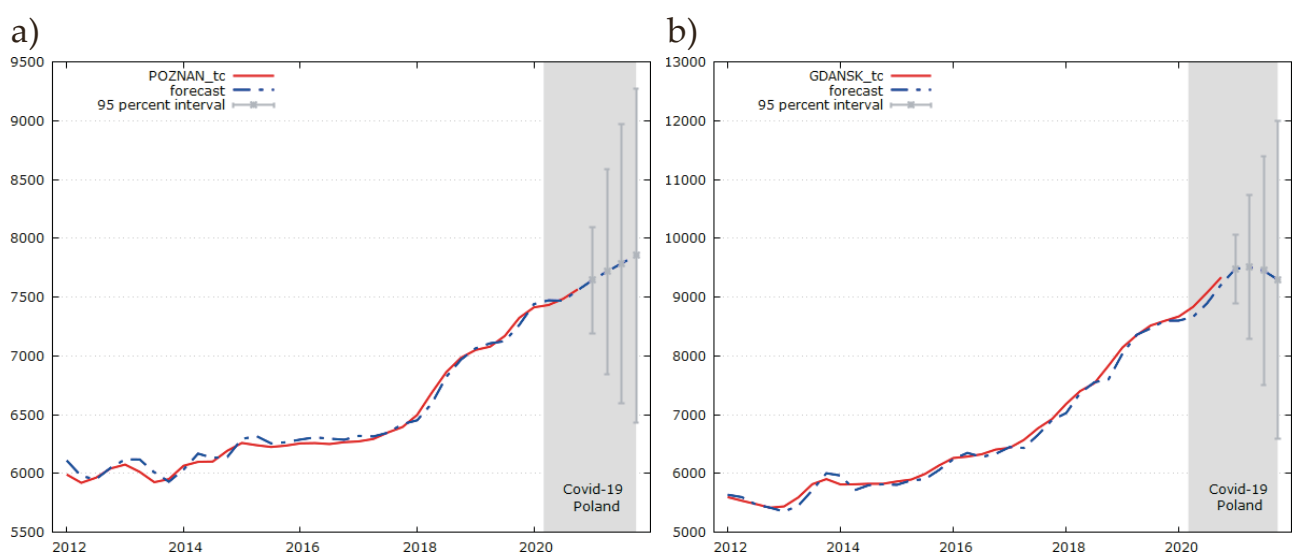

Fig. 7. Time series forecasting results showing the COVID-19 pandemic period:

a) Poznań; b) Gdańsk

Forecasting results, presented in Figures 6 and 7, give inconsistent results. In Warszawa and Poznań, increases are forecasted, while in Kraków and Gdańsk, decreases are forecasted. A discussion of the results obtained with reference to the literature is the subject of the next part of this work.

\section{Literature Review with a Discussion of Results}

Housing is one of the areas of the economy which has a significant effect on the level of satisfying social needs, the dynamics of economic processes, and the effectiveness of developmental activities. Interconnections of housing development and the economy indicate that the former plays a significant role in elevating the level of social, economic, and spatial cohesion of the country [50-52]. According to Urbanavičiene et al. [53] the growth or decline of the housing sector considerably affects the general growth or decline of a country's economy. One of the fundamental tasks of the state and local authorities is fostering conditions conducive for satisfying the residential needs of the society. Housing market in the conditions of market economy requires its efficiency in allocating the existing resources and the possibility of creating a new supply adequate in terms of quality and quantity to the notified demand constitute the outcome of a group with a quite large number of economic and noneconomic factors. The housing market is incontrovertibly local, and hence is primarily shaped by local conditions [54] which include, among others, values characterizing the labor market (unemployment rate, average wage, etc.), factors relating to market size influencing price volatility - the number of inhabitants and households, age structure, marriage rate, etc. [55]. Nevertheless, the price dynamics in this market depend directly on the macroeconomic environment. The strong link between the housing market and the financial market has been strongly accentuated 
as a consequence of the global financial crisis (2006-2007). The almost synergistic reactions of these markets to changes in financial megatrends have been observed. We believe that since 1990 there have been two critical points (supply-demand shock) in the house price dynamics in Poland. The first, Poland's accession to the European Union (in 2004 - results - rapid price increases in 2006-2007) and the second in 2020 (COVID-19 pandemic).

The previous section presented the results of time series analysis of housing prices and their forecasting before and during COVID-19 pandemic. In the process of decomposition and forecasting a TRAMO/SEATS model (Time Series Regression with ARIMA noise, Missing values and Outliers/Signal Extraction in ARIMA Time Series) and ARIMA model (Autoregressive Integrated Moving Average) were used. Forecasting results (January - April 2021), were presented in Figure 5 (Warszawa and Kraków) and Figure 6 (Poznań and Gdańsk). Forecast prices continue longterm upward trend (2013-2020) in Warszawa and Poznań. In Kraków and Gdańsk, the forecast prices change from an increasing trend to a decreasing, for the entire first four months of 2021. The results for the four Polish cities are therefore far from obvious. Based on the nature of the housing market and its much slower response to macroeconomic trends than other markets, it can be assumed that the whole housing market is going through a slowdown phase and Kraków and Gdańsk are reacting earliest to the impact of COVID-19. However, the strong upward trends in Warszawa and Poznan suggest that there will not be significant price declines in Poland in the near future.

In literature, there has been an increasing trend of papers that study the relation between housing prices and the COVID-19 pandemic. Limited studies have observed the direct real estate price dynamics during the COVID-19 pandemic, and most are analysed at an aggregate level [56]. The time series for the Polish four cities in this paper were quarterly aggregated, as for most surveys in other countries (monthly aggregation of prices for certain items). There are still no similar studies in the Polish literature (as in this paper), therefore, the following discussion will present results from other countries. The Turkish housing market has been analysed on the trends from 2010 to 2020, focusing in particular on variations in the period 2019-2020. In this research [57] based on the time series of number of housing sales, it has been shown a decrease (March 2020) and increase (May - June 2020). The reason for the decline was the almost a standstill in the demand for real estate investment. The booming of transactions experienced in June because decreases of interest rates on housing loans and mortgages and possibility to conduct all transactions made online. This behaviour of the housing market does not confirm, the expected recession at the beginning of COVID-19 pandemic, in the housing markets. In Italy in Padua [11] as well the increase in the number of transactions (in the COVID-19 period) has been found 4\% higher than in the same period in 2019. Importantly, flat buyers are very interested in large flats $\left(\right.$ over $\left.100 \mathrm{~m}^{2}\right)$ with a terrace or garden. The raw data in USA show an increasing trend in home listings and 
pending sales after April 16, 2020. According to the authors [58] of this study, it is not clear whether this increasing trend will continue in the long-run and the pandemic will have a significant impact on housing prices. In China [56], considering microlevel housing transaction data in 62 areas from nine districts in Wuhan City from January 2019 to July 2020 has shown the 5.0-7.0\% year-on-year fall in house prices and prices rebounded after the lockdown period. The research results presented above shows that the results of the research presented in this paper confirm the general international trend.

Wang [12] in a study concerning the effect of COVID-19 on house prices, used a revised difference-in-difference method with nonparametric smoothing. The results of these studies are convergent with the results presented in this work, because the cities under study (United States) saw increases in house prices during COVID-19. The largest increase rate of $9.97 \%$ appears in Santa Clara, followed by Irvine with a growth rate of $5.80 \%$. This study showed also that the Honolulu is the only place that experienced declines in house prices with the largest decrease rate approaching 6.69\% in April 2020. The decreases in transactions in the residential market of $15.5 \%$ (in the first quarter of 2020) compared to the same period in 2019 have been shown in the Italian housing market [11]. In my research, in one of the analysed cities (Kraków) there were also dwelling price decreases (starting from Q2 2020) but the forecasting price dynamics showed possible decreases in two cities (Kraków and Gdańsk). In a similar study in China [59] using the difference-in-difference method, it has been shown that the impact of COVID-19 on housing price only exists in regions with a higher infection level of COVID-19. The research confirmed that the housing prices of the communities with confirmed COVID-19 cases are reduced by $2.47 \%$. The result of these studies, although showing a negative effect of COVID-19, is quite small (less than 3\%). In subsequent studies [60] evaluated the short and mid-run COVID-19 effects on housing prices. To predict real estate dynamics, the economic model of Lotka-Volterra (also known as the "prey-predator" model) was applied. The results of the model indicate a housing price drop of $4.16 \%$ in the short-run and $6.49 \%$ in the mid-run (late 2020 - early 2021). Subsequent studies [61] used time series analysis and panel data to study housing price indices between different cities have intercorrelation, and compare wealth levels in society to COVID-19 and housing index. This research has shown that higher housing price indexes are associated with lower confirmed cases of COVID-19 and lower risks of death due to the disease. They believe that the housing price index is a measure of the wellbeing and wealth of residents.

According to Zhao [62] US Housing Market During COVID-19 has shown a number of characteristic behaviors. First, the growth rate of median housing price during the four months (April - August 2020) since the Federal Reserve's unprecedented monetary easing has accelerated faster than any four-month period in the lead-up to the September 2007 global financial crisis. This so-called stylized fact is similar to the behaviour of the Polish housing market. Residential prices in 
Poland reached their first lead-up in 2006-2007 (Fig. 2) and the other just during the COVID-19 pandemic (Figs. 6, 7). The second finding of this paper is that the increase in housing demand in response to lower mortgage interest rates displays a structural break since March 2020 (housing demand has increased by much more than before). The National Bank of Poland's (NBP) interest rate reduction has also influenced the lower mortgage interest rates in Poland.

We believe that the reasons for sustaining increases in housing prices in Poland are the impact of a significant reduction of interest rates by the NBP in March, April, and May 2020. The lowest interest rates in Poland since 1990, gave a powerful impetus to the migration of money from bank deposits to housing investments. Such conclusions are also confirmed in a study of housing markets in the United States [12], where it was shown that historically low interest rates might fuel rapid growth in areas with strong housing market fundamentals. This paper suggests also that lower interest rates might encourage more transactions in Houston, Honolulu, and Santa Clara, where the increase in transaction volumes were observed. The loan interest rates also decreased in Turkey [57] in the beginning of June 2020, which enabled the sales of mortgage transactions to reach high figures in the purchase of legal entities and a revival started in purchase of investment properties).

\section{Conclusion}

The COVID-19 pandemic is a combined supply and demand shock to the financial and housing market but also an unusual negative shock on the health of society (households) and the national economy. After a phase of housing price decline (since 2008), the previous price peaks (2006-2007) have been significantly exceeded in many cities, in 2020. Therefore, it was expected that COVID-19 pandemic can be a stabilizer factor of the housing market and prices will decrease. It can therefore be assumed that potential price decreases (as a normal market correction) would be a beneficial phenomenon for society in Poland, as the relationship between the average income of society and the price of average housing is currently highly unfavorable (for buyers). The results of the research presented, however, do not indicate significant price declines. The TRAMO/SEATS and ARIMA models were used in this study for the decomposition and forecasting of a time series. The results obtained forecast an increase in prices in Warszawa and Poznan and a stable decrease in Kraków and Gdańsk. The whole housing market might go through a slowdown phase, but the strong upward trends in Warszawa and Poznan suggest that there will not be significant price declines in Poland in the near future. Due to the fact that the research presented in this paper was a multi-case study, the results cannot be generalised to the entire housing market in Poland. However, they may constitute the basis for extended further research, taking into account a larger number of cities and factors influencing housing price dynamics. 
Research on the interaction between the COVID-19 pandemic and the housing market are in the initial phase in Poland. Thus, the results obtained from this study can be characterised as new as well as original and would have significance for the investment decisions of individuals and professionals in the housing market.

\section{Acknowledgements}

The author expresses sincere gratitude to the journal editor and the anonymous reviewers who spent their valued time to provide constructive comments and assistance to improve the quality of this paper.

\section{References}

[1] Baek S., Mohanty S.K., Glambosky M.: COVID-19 and stock market volatility: An industry level analysis. Finance Research Letters, vol. 37, 2020, 101748. https://doi.org/10.1016/j.frl.2020.101748.

[2] Biswas T.K., Das M.C.: Selection of the barriers of supply chain management in Indian manufacturing sectors due to COVID-19 impacts. Operational Research in Engineering Sciences: Theory and Applications, vol. 3(3), 2020, pp. 1-12. https://doi.org/10.31181/oresta2030301b.

[3] Altieri M.A., Nicholls C.I.: Agroecology and the emergence of a post COVID-19 agriculture. Agriculture and Human Values, vol. 37(3), 2020, pp. 525-526. https://doi.org/10.1007/s10460-020-10043-7.

[4] Gössling S., Scott D., Hall C.M.: Pandemics, tourism and global change: a rapid assessment of COVID-19. Journal of Sustainable Tourism, vol. 29(1), 2021, pp. 1-20. https://doi.org/10.1080/09669582.2020.1758708.

[5] Lau H., Khosrawipour V., Kocbach P., Mikolajczyk A., Ichii H., Zacharski M. et al.: The association between international and domestic air traffic and the coronavirus (COVID-19) outbreak. Journal of Microbiology. Immunology and Infection, vol.53(3), 2020, pp.467-472. https://doi.org/10.1016/j.jmii.2020.03.026.

[6] Parnell D., Widdop P., Bond A., Wilson R.: COVID-19, networks and sport. Managing Sport and Leisure, 2020, pp. 1-7. https://doi.org/10.1080/23750472. 2020.1750100.

[7] Sharma A., Borah S.B.: Covid-19 and Domestic Violence: an Indirect Path to Social and Economic Crisis. Journal of Family Violence, 2020. https://doi.org/10.1007/ s10896-020-00188-8.

[8] Baqaee D., Farhi E.: Supply and Demand in Disaggregated Keynesian Economies with an Application to the Covid-19 Crisis. Working Paper 27152, National Bureau of Economic Research, Cambridge, May 2020. https://doi.org/10.3386/ w27152, https://www.nber.org/papers/w27152 [access: 22.03.2021].

[9] del Rio-Chanona R.M., Mealy P., Pichler A., Lafond F., Farmer J.D.: Supply and demand shocks in the COVID-19 pandemic: an industry and occupation perspective. Oxford Review of Economic Policy, vol. 36 (Supplement_1), 2020, pp. S94-S137. https://doi.org/10.1093/oxrep/graa033. 
[10] Castro M.F., Duarte J.B., Brinca P.: Measuring Labor Supply and Demand Shocks during COVID-19. Working Paper 2020-011F, Economic Research Federal Reserve Bank of St. Louis, St. Louis 2020. https://doi.org/10.20955/wp.2020.011, https://research.stlouisfed.org/wp/more/2020-011 [access: 22.03.2021].

[11] De Toro P., Nocca F., Buglione F.: Real Estate Market Responses to the COVID-19 Crisis: Which Prospects for the Metropolitan Area of Naples (Italy)? Urban Science, vol. 5(1), 2021, 23. https://doi.org/10.3390/urbansci5010023.

[12] Wang B.: How Does COVID-19 Affect House Prices? A Cross-City Analysis. Journal of Risk and Financial Management, vol. 14(2), 2021, 47. https://doi.org/ 10.3390/jrfm14020047.

[13] Guterres A.: COVID-19 in an Urban World. United Nations, 2020. https:// www.un.org/en/coronavirus/covid-19-urban-world [access: 22.03.2021].

[14] Bieda A.: Urban renewal and the value of real properties. Studia Regionalne i Lokalne, nr 3 (69), 2017, pp. 5-28. https://doi.org/10.7366/1509499536901.

[15] Rabiei-Dastjerdi H., Matthews S.A., Ardalan A.: Measuring Spatial Accessibility to Urban Facilities and Services in Tehran. Spatial Demography, vol. 6(1), 2018, pp. 17-34. https://doi.org/10.1007/s40980-016-0028-2.

[16] Senetra A., Szarek-Iwaniuk P.: Socio-economic development of small towns in the Polish Cittaslow Network - A case study. Cities, vol. 103, 2020, 102758. https:// doi.org/10.1016/j.cities.2020.102758.

[17] Jaszczak A., Kristianova K., Pochodyła E., Kazak J.K., Młynarczyk K.: Revitalization of Public Spaces in Cittaslow Towns: Recent Urban Redevelopment in Central Europe. Sustainability, vol. 13(5), 2021, 2564. https://doi.org/10.3390/su13052564.

[18] Kisiała W., Rącka I.: Spatial and Statistical Analysis of Urban Poverty for Sustainable City Development. Sustainability, vol. 13(2), 2021, 858. https://doi.org/ 10.3390/su13020858.

[19] Bełej M.: Synergistic Network Connectivity among Urban Areas Based on Non-Linear Model of Housing Prices Dynamics. Real Estate Management and Valuation, vol. 26(4), 2018, pp. 22-34. https://doi.org/10.2478/remav-2018-0033.

[20] Bełej M., Kulesza S., Cellmer R.: Logical Homologies between Housting Prices Dynamics and Damped Harmonic Oscillations. Acta Physica Polonica A, vol. 138(1), 2020, pp. 89-95. https://doi.org/10.12693/APhysPolA.138.89.

[21] Galster G.: William Grigsby and the analysis of housing sub-markets and filtering. Urban Studies, vol. 33(10), 1996, pp. 1797-805. https://doi.org/ 10.1080/0042098966376.

[22] Jiang X., Xu L., Cui Y.: Seasonal Model and Its Application in Short-term Forecasting. [in:] Iyer V., Bhardwaj M., Weller K. (eds.), Proceedings of the 2018 $2^{\text {nd }}$ International Conference on Applied Mathematics, Modelling and Statistics Application (AMMSA 2018), Advances in Intelligent Systems Research, vol. 143, Atlantis Press, 2018, pp. 194-196. https://doi.org/10.2991/ammsa-18.2018.39.

[23] Maciąg A., Pietroń R., Kukla S.: Prognozowanie i symulacja w przedsiębiorstwie. Polskie Wydawnictwo Ekonomiczne, Warszawa 2013. 
[24] Cleveland W.P., Tiao G.C.: Decomposition of Seasonal Time Series: A Model for the Census X-11 Program. Journal of the American Statistical Association, vol. 71(355), 1976, pp.581-587. https://doi.org/10.1080/01621459.1976.10481532.

[25] Gómez V., Maravall Herrero A.: Programs TRAMO and SEATS: instructions for the user (beta version: September 1996). Banco de España - Servicio de Estudios, 1995.

[26] Maravall Herrero A.: An Application of TRAMO-SEATS: Automatic Procedure and Sectoral Aggregation. Working Paper 0207, Banco de España, 2002.

[27] Bee Dagum E., Bianconcini S.: Seasonal Adjustment Based on ARIMA Model Decomposition: TRAMO-SEATS. [in:] Seasonal Adjustment Methods and Real Time Trend-Cycle Estimation, Statistics for Social and Behavioral Sciences, Springer International Publishing, Cham 2016, pp. 115-145. https://doi.org/ 10.1007/978-3-319-31822-6_5.

[28] Mossad A., AlazbaA.:DroughtForecasting Using Stochastic Models ina Hyper-Arid Climate. Atmosphere, vol. 6(4), 2015, pp. 410-30. https://doi.org/10.3390/ atmos6040410.

[29] Kokot S.: The analysis of differences in residential property price indices. Real Estate Management and Valuation, vol. 22(3), 2014, pp. 14-27. https://doi.org/ 10.2478/remav-2014-0023.

[30] Klimach A., Dawidowicz A., Źróbek R.: The Polish land administration system supporting good governance. Land Use Policy, vol. 79, 2018, pp. 547-55. https://doi.org/10.1016/j.landusepol.2018.09.003.

[31] Dawidowicz A., Źróbek R.: A methodological evaluation of the Polish cadastral system based on the global cadastral model. Land Use Policy, vol. 73, 2018, pp. 59-72. https://doi.org/10.1016/j.landusepol.2018.01.037.

[32] GUS: Ludność. Stan i struktura oraz ruch naturalny w przekroju terytorialnym (stan w dniu 31.12.2020) w 2016 r. Główny Urząd Statystyczny, 30.04.2021. https://stat.gov.pl/obszary-tematyczne/ludnosc/ludnosc/ludnosc-stan-i-struktura-ludnosci-oraz-ruch-naturalny-w-przekroju-terytorialnym-stan-w-dniu-31-12-2020,6,29.html [access: 31.12.2020].

[33] Bełej M., Kulesza S.: Real Estate Market under Catastrophic Change. Acta Physica Polonica A, vol. 123(3), 2013, pp. 497-501.

[34] Brzezicka J., Wisniewski R.: Translocality on the real estate market. Land Use Policy, vol. 55, 2016, pp. 166-181. https://doi.org/10.1016/j.landusepol. 2016.03.031.

[35] Siemińska E., Krajewska M.: Conditions and Directions of Investing on the World Real Estate Market. Real Estate Management and Valuation, vol. 25(4), 2017, pp. 99-112. https://doi.org/10.1515/remav-2017-0033.

[36] Forrester J.W.: Lessons from system dynamics modeling. System Dynamics Review, vol. 3(2), 1987, pp. 136-49.

[37] van Geert P.: Dynamic systems approaches and modeling of developmental processes. [in:] Valsiner J., Connolly K.J. (eds.), Handbook of Developmental Psychology, SAGE, 2002, pp. 640-672. 
[38] Łapkowska-Baster B.: Miary współzależności i dynamiki zjawisk w statystyce opisowej: przykłady i zadania. Wydawnictwo Uniwersytetu Jagiellońskiego, Kraków 2009.

[39] Grudkowska S., Nehrebecka N.: Identyfikacja i usuwanie sezonowości z polskich agregatów monetarnych. Materiały i Studia, nr 237, Narodowy Bank Polski, Warszawa 2009.

[40] Zimny A.: Statystyka opisowa: materiały pomocnicze do ćwiczeń. Materiały dydaktyczne, nr 17, Państwowa Wyższa Szkoła Zawodowa w Koninie, 2010.

[41] Cox D.R., Gudmundsson G., Lindgren G., Bondesson L., Harsaae E., Laake P. et al.: Statistical analysis of time series: Some recent developments [with discussion and reply]. Scandinavian Journal of Statistics, vol. 8, 1981, pp.93-115.

[42] Wooldridge J.M.: Econometric Analysis of Cross Section and Panel Data. MIT Press, Cambridge 2002.

[43] Hannonen M.: An analysis of land prices: A structural time-series approach. International Journal of Strategic Property Management, vol. 9(3), 2005, pp. 145-172. http://dx.doi.org/10.3846/1648715X.2005.9637534.

[44] McDowall D., McCleary R., Bartos B.J.: Interrupted Time Series Analysis. Oxford University Press, Oxford 2019.

[45] Fernandez-Perez A., Gilbert A., Indriawan I., Nguyen N.H.: COVID-19 pandemic and stock market response: A culture effect. Journal of Behavioral and Experimental Finance, vol. 29, 2021, 100454. https://doi.org/10.1016/ j.jbef.2020.100454.

[46] Ali M., Alam N., Rizvi S.A.R.: Coronavirus (COVID-19) - An epidemic or pandemic for financial markets. Journal of Behavioral and Experimental Finance, vol. 27, 2020, 100341. https://doi.org/10.1016/j.jbef.2020.100341.

[47] Izzeldin M., Muradoğlu Y.G., Pappas V., Sivaprasad S.: The impact of Covid-19 on G7 stock markets volatility: Evidence from a ST-HAR model. International Review of Financial Analysis, vol. 74, 2021, 101671. https://doi.org/10.1016/ j.irfa.2021.101671.

[48] Contessi S., De Pace P.: The international spread of COVID-19 stock market collapses. Finance Research Letters, 2021, 101894. https://doi.org/10.1016/ j.frl.2020.101894.

[49] Milcheva S.: Volatility and the Cross-Section of Real Estate Equity Returns during Covid-19. The Journal of Real Estate Finance and Economics, 2021. https:// doi.org/10.1007/s11146-021-09840-6.

[50] Case K.E., Quigley J.M., Shiller R.J.: Comparing wealth effects: the stock market versus the housing market. Advances in Macroeconomics, vol. 5(1), 2005, pp. 1235-1235. https://doi.org/10.2202/1534-6013.1235.

[51] Lis P.: Wahania cykliczne rynków mieszkaniowych: aspekty teoretyczne i praktyczne. Wydawnictwo Adam Marszałek, Toruń 2012.

[52] Ball M.: Housing policy and economic power: the political economy of owner occupation. University Paperbacks, vol. 828, Routledge, 2017. 
[53] Urbanavičiene V., Kaklauskas A., Zavadskas E.K.: The conceptual model of construction and real estate negotiation. International Journal of Strategic Property Management, vol. 13(1), 2009, pp. 53-70. https://doi.org/10.3846/1648715X.2009.13.53-70.

[54] Abraham J.M., Hendershott P.H.: Patterns and Determinants of Metropolitan House Prices, 1977-91. NBER Working Paper 4196, National Bureau of Economic Research, Cambridge 1992.

[55] Beltratti A., Morana C.: International house prices and macroeconomicfluctuations. Journal of Banking \& Finance, vol. 34(3), 2010, pp. 533-545. https://doi.org/ 10.1016/j.jbankfin.2009.08.020.

[56] Cheung K.S., Yiu C.Y., Xiong C.: Housing Market in the Time of Pandemic: A Price Gradient Analysis from the COVID-19 Epicentre in China. Journal of Risk and Financial Management, vol. 14(3), 2021, 108. https://doi.org/10.3390/ jrfm14030108.

[57] Tanrivermiş H.: Possible impacts of COVID-19 outbreak on real estate sector and possible changes to adopt: A situation analysis and general assessment on Turkish perspective. Journal of Urban Management, vol. 9(3), 2020, pp. 263-269. https://doi.org/10.1016/j.jum.2020.08.005.

[58] Yoruk B.: Early Effects of the COVID-19 Pandemic on Housing Market in the United States. Social Science Research Network, May 2020. https://doi.org/ 10.2139/ssrn.3607265.

[59] Qian X., Qiu S., Zhang G.: The impact of COVID-19 on housing price: Evidence from China. Finance Research Letters, 2021, 101944. https://doi.org/ 10.1016/j.frl.2021.101944.

[60] Del Giudice V., De Paola P., Del Giudice F.P.: COVID-19 Infects Real Estate Markets: Short and Mid-Run Effects on Housing Prices in Campania Region (Italy). Social Sciences, vol. 9(7), 2020, 114. https://doi.org/10.3390/socsci9070114.

[61] Pichler M., Skutnik F., Vlad A., Shahri H., Ridwan M.: Housing Price Index, Wealth, and Protective Shield against Covid-19. SIASAT. 2021, vol. 6(1), pp. 1-8. https://doi.org/10.33258/siasat.v6i1.84.

[62] Zhao Y.: US Housing Market During COVID-19: Aggregate and Distributional Evidence. COVID Economics, vol. 50, 2020, pp. 113-154. https://dx.doi.org/ $10.2139 /$ ssrn.3677651. 